\title{
Evaluation of fermented whole crop wheat and barley feeding on growth performance, nutrient digestibility, faecal volatile fatty acid emission, blood constituents, and faecal microbiota in growing pigs
}

\author{
C. H. Lee ${ }^{1}$, W. Yun ${ }^{1}$, J. H. Lee ${ }^{1}$, W. G. Kwak ${ }^{1}$, S. Y. Oh ${ }^{1}$, S. J. Park ${ }^{1}$, T. H. Song ${ }^{2}$, T. I. Park ${ }^{2}$ \& \\ J. H. Cho ${ }^{1 \#}$ \\ ${ }^{1}$ Department of Animal Science Chungbuk National University 52 Naesudong-ro, Heungdeok-gu, Cheongju, Chungbuk, \\ 361-763, South Korea \\ ${ }^{2}$ National Institute of Crop Science, Wanjugun 565-851, South Korea
}

(Received 19 January 2017; Accepted 24 February 2017; First published online 11 July 2017)

Copyright resides with the authors in terms of the Creative Commons Attribution 4.0 South African License.

See: $h$ ttp://creativecommons.org/licenses/by/4.0/za

Condition of use: The user may copy, distribute, transmit and adapt the work, but must recognize the authors and the South African Journal of Animal Science.

\begin{abstract}
This study was conducted to determine the effects of feeding diets with fermented whole crop wheat (FWW) and fermented whole crop barley (FWB) on growth performance, nutrient digestibility, blood constituents, faecal volatile fatty acid (VFA) emission and faecal microbiota in growing pigs. A total of 200 growing pigs were randomly allotted to five treatments with eight replicates per treatment and five pigs per replicate. Dietary treatments consisted of i) $\mathrm{CON}$ (basal diet), ii) $0.5 \% \mathrm{FWW}$ (CON + 0.5\% fermented whole crop wheat), iii) $1.0 \% \mathrm{FWW}$ (CON $+1.0 \%$ fermented whole crop wheat), iv) $0.5 \%$ FWB (CON + 0.5\% fermented whole crop barley), and v) $1.0 \%$ FWB (CON $+1.0 \%$ fermented whole crop barley). The digestibility of total dietary fibre was significantly higher in pigs fed FWW diets. The faecal emissions of VFA of pigs fed the fermented treatments was increased significantly compared with CON. Concentrations of cortisol and triglyceride in blood of pigs fed $1.0 \%$ FWW were significantly lower than pigs fed CON diets. The pigs fed 1.0\% FWB diets had a significantly decreased level of total cholesterol in blood compared with CON. In conclusion, the current results indicated that diets supplemented with FWW and FWB could increase faecal VFA emission and reduce concentration of triglyceride and cortisol, while $0.5 \%$ and $1.0 \%$ FWW had no negative effects on growth performance, and could increase digestibility of dietary fibre in growing pigs.
\end{abstract}

Keywords: Dietary fibre, faecal short-chain fatty acid emissions, fermented feed, serum parameter, swine

\#Corresponding author: jinhcho@cbnu.ac.kr

\section{Introduction}

Because of the ban on the use of antibiotics in feed as a growth promoter in Europe, research on alternative antibiotic drugs is needed. After maize, wheat and barley are produced in large quantities and account for a large proportion of winter crops. However, the whole crop cereal has high fibre content and may be poorly available for pig digestion. In general, the digestibility of nutrients is affected when pigs are fed dietary fibre, which is the sum of non-starch polysaccharides (NSP) and lignin (Knudsen \& Hansen, 1991). Owing to the lack of endogenous enzymes for its digestion, the fibre component of a diet is fermented through microbial degradation in the cecum and colon. However, in the process, there could be pronounced negative effects on the utilization of other components.

Fermentation can be applied to pig feed as an alternative to antibiotic use as a growth promoter, as it does not adversely affect growth performance because it reduces factors that inhibit the growth of pigs (Skrede et al., 2001; Brooks, 2008; Jørgensen et al., 2010). Through fermentation, beneficial bacteria are increased and harmful microorganisms are decreased, which has a positive effect on the microorganisms in the gastrointestinal tract and the beneficial effect of increasing preference because of higher levels of lactic acid (Van Winsen et al., 2001; Meeske, 2005). The VFAs that are made from fermented fibre by microbial activity are absorbed and metabolized promptly (Metzler, 2007), and have a nutritional effect on the intestinal epithelium in pigs (Metzler \& Mosenthin, 2008). Increasing the concentrations of VFA lowers intestinal digesta pH, reduces the number of acid-sensitive Enterobacteria, and increases beneficial bacteria (O'Connell et al., 2005).

With a view to implementing fibre diets in the pig industry, the benefits of fermented barley and wheat have been investigated with regard to the health and productivity of pigs (Moran et al., 2006; Givens et al., 
2009; Hargreaves et al., 2009). These fermented diets contain probiotics, which can improve the performance and intestinal health of pigs (Lindberg, 2014; Canibe \& Jensen, 2007).

Although there are studies on fermented liquid wheat and diet feed (Canibe \& Jensen, 2012; Missotten et al., 2015), there are few studies on the effect of solid state FWW and FWB in pigs. They may also be effective in promoting animal health and growth in pigs. Thus, the objective of this study was to evaluate the effects of FWW and FWB as feed ingredients on growth performance, nutrient digestibility, faecal VFA emission, blood profile, and faecal microbiota in growing pigs.

\section{Material and methods}

This experiment was conducted at the Experimental Unit of Chungbuk National University. All protocols were approved by the Animal Care and Use Committee of Chungbuk National University.

Wheat and barley were harvested on the 40th and 35th days after heading, respectively, and were ground in a hammer mill to pass through a 5-mm screen. The inoculum was then treated and fermented for 40 days in the gunny bag. The inoculated microorganisms that were used as fermentation additives in this study were Lactobacillus sp. 3-1, 5-1, 14-1, as recommended by the National Institute of Agricultural Sciences, which were isolated from rice straw silage and have similar properties to $L$. plantarum.

A total of 200 pigs ((Landrace $x$ Yorkshire) $x$ Duroc) with initial body weight (IBW) of $23 \mathrm{~kg} \pm 0.5 \mathrm{~kg}$ were used in a 42-day trial. At the beginning of the experiment, the pigs were allotted to one of five dietary treatment groups on the basis of IBW in accordance with a randomized complete block design. There were eight replications per treatment, with five pigs per pen. The dietary treatments consisted of i) CON (basal diet), ii) $0.5 \% \mathrm{FWW}$ (CON + 0.5\% fermented whole crop wheat), iii) $1.0 \% \mathrm{FWW}$ (CON $+1.0 \%$ fermented whole crop wheat), iv) $0.5 \%$ FWB (CON $+0.5 \%$ fermented whole crop barley), and v) $1.0 \%$ FWB (CON $+1.0 \%$ fermented whole crop barley). The diets employed in this experiment fulfilled or exceeded the NRC (2012) recommendations for all nutrients, regardless of treatment (Table 1). Table 2 shows the nutrient composition and in vitro digestion of wheat and barley. Throughout the experimental period, the pigs were permitted $a d$ libitum access to feed and water with self-feeders and nipple water.

Pigs were weighed individually on day 1 , day 21 , and day 42 of the experiment. Feed consumption was determined on a pen basis. This information was used to calculate the average daily gain (ADG), average daily feed intake (ADFI), and gain/feed ratio $(\mathrm{G} / \mathrm{F})$. Chromic oxide $(0.20 \%)$ was added as an inert indicator to calculate the apparent digestibility of dry matter (DM), nitrogen $(\mathrm{N})$, and energy. Fresh faecal grab samples were obtained from each pen every day of the last week of the experiment ( 7 days). These samples were then dried at $70{ }^{\circ} \mathrm{C}$ for 72 hours, after which they were finely ground in order to pass thorough a 1-mm screen, and analysed for DM (method 930.15) (AOAC, 2006), N (method 968.06) (AOAC, 2000), total dietary fibre (TDF), and insoluble dietary fibre (IDF) (method 985.29) AOAC, 2006). The concentration of soluble dietary fibre (SDF) was calculated as the difference between TDF and IDF. Gross energy (GE) was determined by measuring the heat of combustion in the samples with a bomb calorimeter (Parr 6100; Parr instrument Co., Moline, II, USA). Chromium levels were determined by UV absorption spectrophotometry (Shimadzu, UV-1201, Japan), following the method described by Williams et al. (1962). Apparent total tract digestibility (ATTD) was calculated according to the following formula:

$$
\operatorname{ATTD}(\%)=\left[1-\left\{\left(\mathrm{N}_{\mathrm{f}} \times \mathrm{C}_{\mathrm{d}}\right) /\left(\mathrm{N}_{\mathrm{d}} \times \mathrm{C}_{\mathrm{f}}\right)\right\}\right] \times 100
$$

Where: $N_{f}=$ nutrient concentration in faeces (\% DM)

$\mathrm{N}_{\mathrm{d}}=$ nutrient concentration in diets $(\% \mathrm{DM})$

$\mathrm{C}_{\mathrm{f}}=$ chromium concentration in faeces $(\% \mathrm{DM}$

$\mathrm{C}_{\mathrm{d}}=$ chromium concentration in diets (\% DM) (Lei \& Kim, 2014)

At the end of the experiment, two pigs from each pen were randomly selected and blood samples were collected by jugular venipuncture. Blood samples were collected into vacuum tubes containing no additives to obtain serum. The serum was separated by centrifugation for $15 \mathrm{~min}$ at $3000 \times \mathrm{g}$ at $4{ }^{\circ} \mathrm{C}$, after which total cholesterol, HDL cholesterol, LDL cholesterol, triglyceride, cortisol, and blood urea nitrogen (BUN) concentrations were determined with an automatic biochemistry analyser (Hitachi 747, Tokyo, Japan). To measure faecal microbiota and faecal VFA emission, faecal samples were collected from two pigs randomly selected from each pen by massaging the rectum at the end of the experiment according to the method described by Yan et al. (2012). The composite faecal sample $(1 \mathrm{~g})$ from each pen was diluted with $9 \mathrm{ml}$ of 10 $\mathrm{g} / \mathrm{L}$ peptone broth (Becton Dickinson \& Co., Franklin Lakes, NJ) and then homogenized. Viable counts of bacteria in the faecal samples were conducted by plating serial 10 -fold dilutions (in $10 \mathrm{~g} / \mathrm{L}$ peptone solution) onto MacConkey agar plates (Difco Laboratories, Detroit, Mi, USA) and lactobacilli medium agar plates to isolate the coliform bacteria and Lactobacillus, respectively. The MacConkey agar plates were incubated for 
Table 1 The composition of diet used in feeding trial

\begin{tabular}{|c|c|c|c|c|c|}
\hline \multirow{2}{*}{ Items } & \multirow{2}{*}{ CON } & \multicolumn{2}{|c|}{ FWW } & \multicolumn{2}{|c|}{ FWB } \\
\hline & & 0.5 & 1.0 & 0.5 & 1.0 \\
\hline \multicolumn{6}{|l|}{ Ingredients $(\mathrm{g} / \mathrm{kg})$} \\
\hline Maize & 577.10 & 572.10 & 567.10 & 572.10 & 567.10 \\
\hline Soybean meal & 324.5 & 324.5 & 324.5 & 324.5 & 324.5 \\
\hline Wheat bran & 50.0 & 50.0 & 50.0 & 50.0 & 50.0 \\
\hline FWW & & 5.0 & 10.0 & & \\
\hline FWB & & & & 5.0 & 10.0 \\
\hline Soybean oil & 20.0 & 20.0 & 20.0 & 20.0 & 20.0 \\
\hline L-Lysine & 0.80 & 0.80 & 0.80 & 0.80 & 0.80 \\
\hline DL-Methionine & 0.80 & 0.80 & 0.80 & 0.80 & 0.80 \\
\hline L-Threonine & 0.30 & 0.30 & 0.30 & 0.30 & 0.30 \\
\hline Dicalcium phosphate & 14.70 & 14.70 & 14.70 & 14.70 & 14.70 \\
\hline Limestone & 6.30 & 6.30 & 6.30 & 6.30 & 6.30 \\
\hline Salt & 2.50 & 2.50 & 2.50 & 2.50 & 2.50 \\
\hline $\operatorname{Min} m i x^{1}$ & 1.0 & 1.0 & 1.0 & 1.0 & 1.0 \\
\hline Vit $m i^{2}$ & 2.0 & 2.0 & 2.0 & 2.0 & 2.0 \\
\hline \multicolumn{6}{|c|}{ Chemical composition $(\mathrm{g} / \mathrm{kg}$ ) } \\
\hline ME (Mcal/kg) & 3.2 & 3.2 & 3.2 & 3.2 & 3.2 \\
\hline Crude protein & 199.6 & 199.7 & 199.9 & 199.8 & 199.9 \\
\hline Lysine & 11.63 & 11.64 & 11.64 & 11.63 & 11.64 \\
\hline Methionine & 3.88 & 3.88 & 3.88 & 3.88 & 3.88 \\
\hline Calcium & 6.8 & 6.8 & 6.8 & 6.8 & 6.8 \\
\hline Total phosphorus & 7.0 & 7.0 & 7.0 & 7.0 & 7.0 \\
\hline
\end{tabular}

FWW: fermented whole crop wheat; FWB: fermented whole crop barley; ME: metabolizable energy

${ }^{1}$ Provided per kilogram of diet: $37.5 \mathrm{mg}$ of $\mathrm{Zn}, 37.5 \mathrm{mg}$ of $\mathrm{Mn}, 37.5 \mathrm{mg}$ of Fe, $3.75 \mathrm{mg}$ of Cu, $0.83 \mathrm{mg}$ of I, $62.5 \mathrm{mg}$ of S, and $0.23 \mathrm{mg}$ of $\mathrm{Se}$

${ }^{2}$ Provided per kilogram of diet: 15,000 IU of vitamin A, 3,750 IU of vitamin D3, $37.5 \mathrm{mg}$ of vitamin E, $2.55 \mathrm{mg}$ of vitamin

$\mathrm{K} 3,3 \mathrm{mg}$ of thiamin, 7. Mg of riboflavin, $4.5 \mathrm{mg}$ of vitamin B6, $24 \mu \mathrm{g}$ of vitamin B12, $51 \mathrm{mg}$ of niacin, $1.5 \mathrm{mg}$ of folic acid, $0.2 \mathrm{mg}$ of biotin, and $13.5 \mathrm{mg}$ of pantothenic acid

${ }^{3}$ Calculated

24 hours at $37{ }^{\circ} \mathrm{C}$. The lactobacilli medium agar plates were then incubated for 48 hours at $39{ }^{\circ} \mathrm{C}$ under anaerobic conditions. E. coli and Lactobacillus colonies were counted immediately after removal from the incubator.

A total of $300 \mathrm{~g}$ of fresh faeces samples from each pen was fermented in $2.6 \mathrm{~L}$ plastic boxes for 24 hours at room temperature. After the fermentation period, a Gastec (model GV-100, Gastec, Japan) gas sampling pump was utilized for gas detection (No. $81 \mathrm{~L}$ for acetic acid and $81 \mathrm{~L}^{*}$ for butyric acid) (Gastec Corp., Kanagawa, Japan).

All data were analysed by ANOVA using the general linear model (GLM) procedure of SAS (SAS, 2008), with the pen being defined as the experimental unit. Differences among treatments were determined with Duncan's multiple range tests. The results were expressed as the least square means \pm SEM and the differences between treatments were considered statistically significant if $P<0.05$. 
Table 2 Chemical analysis and in vitro digestibility of wheat and barley

\begin{tabular}{|c|c|c|c|}
\hline Items & Wheat & Barley & SE \\
\hline \multicolumn{4}{|c|}{ Composition (g/kg) } \\
\hline Crude protein & 98.9 & 137.6 & \\
\hline Crude fat & 22.3 & 25.9 & \\
\hline Crude fibre & 264.6 & 249.4 & \\
\hline Ash & 88.4 & 76.8 & \\
\hline NDF & 567.7 & 515.2 & \\
\hline ADF & 320.7 & 306.1 & \\
\hline ME (Mcal/kg) & 4.1 & 3.9 & \\
\hline \multicolumn{4}{|c|}{ In vitro digestion (\%) } \\
\hline DM digestion & 54.42 & 52.57 & 1.10 \\
\hline OM digestion & 68.50 & 66.40 & 0.86 \\
\hline
\end{tabular}

DM: dry matter; OM, organic matter; ME: metabolizable energy

SE: standard error

\section{Results}

The results of the growth performance are presented in Table 3. The CON treatment was significantly improved $(P<0.05)$ in ADG compared with $0.5 \%$ FWB treatment at weeks $0-6$. There was no significant difference in ADG between CON and FWW. ADFI of 1.0\% FWW and 1.0\% FWB treatment was decreased $(P$ $<0.05)$ compared with CON treatment at weeks 3-6.

Table 3 Effect of fermented whole crop wheat and barley diets on growth performance in growing pigs

\begin{tabular}{lcccccc}
\hline \multirow{2}{*}{ Items } & CON & \multicolumn{3}{c}{ FWW } & \multicolumn{3}{c}{ FWB } & \multirow{2}{*}{ SE } \\
\cline { 3 - 5 } & & $\mathbf{0 . 5}$ & $\mathbf{1 . 0}$ & $\mathbf{0 . 5}$ & $\mathbf{1 . 0}$ & \\
\hline Weight, kg & & & & & & \\
$\quad$ Initial weight & 23.26 & 22.95 & 22.98 & 22.95 & 22.98 & 0.65 \\
$\quad$ Weight (3 weeks) & 36.58 & 35.80 & 35.81 & 35.04 & 35.29 & 0.72 \\
$\quad$ Final weight & 52.86 & 50.85 & 51.32 & 50.07 & 51.09 & 0.75 \\
Daily weight gain, kg & & & & & & \\
0-3 weeks & 0.634 & 0.612 & 0.611 & 0.576 & 0.586 & 0.043 \\
3-6 weeks & 0.775 & 0.717 & 0.738 & 0.715 & 0.752 & 0.031 \\
0-6 weeks & $0.705^{\mathrm{a}}$ & $0.664^{\mathrm{ab}}$ & $0.675^{\mathrm{ab}}$ & $0.646^{\mathrm{b}}$ & $0.669^{\mathrm{ab}}$ & 0.010 \\
Daily feed intake, kg & & & & & & \\
$\quad$ 0-3 weeks & 1.117 & 1.097 & 1.096 & 1.099 & 1.093 & 0.019 \\
3-6 weeks & $1.475^{\mathrm{a}}$ & $1.404^{\mathrm{ab}}$ & $1.362^{\mathrm{c}}$ & $1.380^{\mathrm{bc}}$ & $1.376^{\mathrm{c}}$ & 0.030 \\
0-6 weeks & $1.296^{\mathrm{a}}$ & $1.250^{\mathrm{b}}$ & $1.229^{\mathrm{b}}$ & $1.239^{\mathrm{b}}$ & $1.234^{\mathrm{b}}$ & 0.021 \\
Feed efficiency & & & & & & \\
0-3 weeks & 0.568 & 0.558 & 0.557 & 0.524 & 0.536 & 0.021 \\
3-6 weeks & 0.529 & 0.511 & 0.542 & 0.518 & 0.547 & 0.022 \\
0-6 weeks & 0.545 & 0.531 & 0.549 & 0.521 & 0.542 & 0.03
\end{tabular}

CON: basal diet; $0.5 \%$ FWW: control diet $+0.5 \%$ fermented whole crop wheat; $1.0 \%$ FWW: control diet $+1.0 \%$ fermented whole crop wheat; $0.5 \%$ FWB: control diet $+0.5 \%$ fermented whole crop barley; $1.0 \%$ FWB: control diet $+1.0 \%$ fermented whole crop barley.

$a, b, c$ Means in the same row with different superscripts differ $(P<0.05)$. SE: standard error 
Furthermore, the ADFI of CON treatment was higher $(P<0.05)$ than other treatments in weeks $0-6$. There was no significant difference in feed efficiency among treatments.

Table 4 shows nutrient digestibility in pigs. The digestibility of DM, N, and GE was lower $(P<0.05)$ in pigs fed $1.0 \%$ FWB compared with pigs fed the CON diet. Digestibility of TDF, SDF, and IDF was improved $(P<0.05)$ in pigs fed $0.5,1.0 \%$ FWW compared with CON treatments.

Table 4 Effect of fermented whole crop wheat and barley diets on nutrient digestibility in growing pigs

\begin{tabular}{lcccccc}
\hline \multirow{2}{*}{ Items, \% } & CON & \multicolumn{2}{c}{ FWW } & \multicolumn{2}{c}{ FWB } & SE \\
\cline { 3 - 6 } & & $\mathbf{0 . 5}$ & $\mathbf{1 . 0}$ & $\mathbf{0 . 5}$ & $\mathbf{1 . 0}$ & \\
\hline $\mathrm{NM}$ & $84.3^{\mathrm{a}}$ & $82.2^{\mathrm{ab}}$ & $81.2^{\mathrm{ab}}$ & $81.2^{\mathrm{ab}}$ & $79.7^{\mathrm{b}}$ & 1.02 \\
$\mathrm{~N}$ & $79.2^{\mathrm{a}}$ & $75.5^{\mathrm{ab}}$ & $73.2^{\mathrm{ab}}$ & $70.3^{\mathrm{bc}}$ & $70.1^{\mathrm{c}}$ & 1.54 \\
$\mathrm{GE}$ & $82.4^{\mathrm{a}}$ & $82.2^{\mathrm{a}}$ & $79.5^{\mathrm{ab}}$ & $80.0^{\mathrm{ab}}$ & $79.1^{\mathrm{b}}$ & 0.55 \\
Total dietary fibre & $78.6^{\mathrm{b}}$ & $82.2^{\mathrm{a}}$ & $81.5^{\mathrm{a}}$ & $80.2^{\mathrm{ab}}$ & $80.3^{\mathrm{ab}}$ & 0.65 \\
Soluble dietary fibre & $83.5^{\mathrm{b}}$ & $87.6^{\mathrm{a}}$ & $87.2^{\mathrm{a}}$ & $86.5^{\mathrm{ab}}$ & $85.9^{\mathrm{ab}}$ & 0.88 \\
Insoluble dietary fibre & $74.5^{\mathrm{b}}$ & $78.8^{\mathrm{a}}$ & $78.1^{\mathrm{a}}$ & $77.5^{\mathrm{ab}}$ & $76.8^{\mathrm{ab}}$ & 0.24
\end{tabular}

GE: gross energy; CON: basal diet; 0.5\% FWW: control diet + 0.5\% fermented whole crop wheat; $1.0 \%$ FWW: control diet $+1.0 \%$ fermented whole crop wheat; $0.5 \%$ FWB: control diet $+0.5 \%$ fermented whole crop barley; $1.0 \%$ FWB: control diet $+1.0 \%$ fermented whole crop barley

$a, b, c$ Means in the same row with different superscripts differ $(P<0.05)$

SE: standard error

Table 5 shows faecal VFA emission of supplementation diets of FWB, and FWW. Feeding FWW and FWB diets to growing pigs resulted in a significant increase in faecal emissions of acetic acid and butyric acid compared with pigs fed a basal diet.

Table 5 Effect of fermented whole crop wheat and barley diets on volatile fatty acid emission in growing pigs

\begin{tabular}{|c|c|c|c|c|c|c|}
\hline \multirow{2}{*}{ Items, ppm } & \multirow{2}{*}{ CON } & \multicolumn{2}{|c|}{ FWW } & \multicolumn{2}{|c|}{ FWB } & \multirow{2}{*}{ SE } \\
\hline & & 0.5 & 1.0 & 0.5 & 1.0 & \\
\hline Acetic acid & $8.40^{d}$ & $11.48^{\mathrm{c}}$ & $12.33^{b c}$ & $14.07^{\mathrm{ab}}$ & $14.63^{\mathrm{a}}$ & 0.71 \\
\hline Butyric acid & $10.92^{d}$ & $14.93^{\mathrm{C}}$ & $16.03^{b c}$ & $18.29^{\mathrm{ab}}$ & $19.02^{\mathrm{a}}$ & 0.92 \\
\hline
\end{tabular}

CON: basal diet; $0.5 \%$ FWW: control diet $+0.5 \%$ fermented whole crop wheat; $1.0 \%$ FWW: control diet $+1.0 \%$ fermented whole crop wheat; $0.5 \%$ FWB: control diet + 0.5\% fermented whole crop barley; $1.0 \%$ FWB: control diet $+1.0 \%$ fermented whole crop barley

a, b, c, d Means in the same row with different superscripts differ $(P<0.05)$

SE: standard error

The results of the blood profile are presented in Table 6. In terms of the total cholesterol in blood, the $1.0 \%$ FWB treatment was lowest, and there were no significant differences among the other four treatments. Pigs fed the diets with FWW, 1.0\% FWB treatments had significantly reduced triglyceride and cortisol levels, and $1.0 \%$ FWW treatment was the lowest. There were no significant differences in HDL cholesterol, LDL cholesterol and BUN among treatments.

The results of the faecal microorganisms are presented in Table 7. In the present study, there were no significant differences in Lactobacillus and E. coli counts in faeces among treatments. 
Table 6 Effect of fermented whole crop wheat and barley diets on blood profile in growing pigs

\begin{tabular}{lllllll}
\hline Items & \multirow{2}{*}{ CON } & FWW & \multicolumn{3}{l}{ FWB } & SE \\
\cline { 3 - 7 } & & $\mathbf{0 . 5}$ & $\mathbf{1 . 0}$ & $\mathbf{0 . 5}$ & $\mathbf{1 . 0}$ & \\
\hline Total cholesterol (ml/dl) & $104.50^{\mathrm{a}}$ & $98.75^{\mathrm{ab}}$ & $94.75^{\mathrm{ab}}$ & $98.00^{\mathrm{ab}}$ & $87.00^{\mathrm{b}}$ & 4.21 \\
HDL cholesterol $(\mathrm{ml} / \mathrm{dl})$ & 31.50 & 30.75 & 34.75 & 31.50 & 32.75 & 5.22 \\
LDL cholesterol $(\mathrm{ml} / \mathrm{dl})$ & 58.00 & 57.35 & 54.85 & 56.15 & 58.35 & 4.21 \\
Triglycerides $(\mathrm{ml} / \mathrm{dl})$ & $40.00^{\mathrm{a}}$ & $33.25^{\mathrm{b}}$ & $30.75^{\mathrm{c}}$ & $31.75^{\mathrm{c}}$ & $34.50^{\mathrm{b}}$ & 1.02 \\
BUN (mg/dl) & 22.98 & 18.68 & 23.73 & 21.75 & 23.88 & 1.38 \\
Cortisol $(\mathrm{mg} / \mathrm{dl})$ & $3.53^{\mathrm{a}}$ & $2.48^{\mathrm{bc}}$ & $1.10^{\mathrm{c}}$ & $2.90^{\mathrm{ab}}$ & $2.53^{\mathrm{bc}}$ & 0.38
\end{tabular}

BUN: blood urea nitrogen; CON: basal diet; 0.5\% FWW: control diet + 0.5\% fermented whole crop wheat; $1.0 \%$ FWW: control diet $+1.0 \%$ fermented whole crop wheat; $0.5 \%$ FWB: control diet $+0.5 \%$ fermented whole crop barley; $1.0 \%$ FWB: control diet $+1.0 \%$ fermented whole crop barley

a, b, c Means in the same row with different superscripts differ $(P<0.05)$

SE: standard error

Table 7 Effect of fermented whole wheat and barley diets on faecal microbial shedding in growing pigs

\begin{tabular}{|c|c|c|c|c|c|c|}
\hline \multirow{2}{*}{ Items, $\log _{10} \mathrm{cfu} / \mathrm{g}$} & \multirow{2}{*}{ CON } & \multicolumn{2}{|c|}{ FWW } & \multicolumn{2}{|c|}{ FWB } & \multirow{2}{*}{ SE } \\
\hline & & 0.5 & 1.0 & 0.5 & 1.0 & \\
\hline Lactobacillus & 7.66 & 7.62 & 7.59 & 7.64 & 7.65 & 0.05 \\
\hline E. coli & 6.23 & 6.21 & 6.20 & 6.24 & 6.19 & 0.41 \\
\hline
\end{tabular}

CON: basal diet; $0.5 \%$ FWW: control diet $+0.5 \%$ fermented whole crop wheat; $1.0 \%$ FWW: control diet $+1.0 \%$ fermented whole crop wheat; $0.5 \%$ FWB: control diet $+0.5 \%$ fermented whole crop barley; $1.0 \%$ FWB: control diet $+1.0 \%$ fermented whole crop barley

\section{Discussion}

In terms of growth performance, there were no significant differences in the final weights among treatments, although the $0.5 \%$ FWB treatment led to a significantly lower ADG than CON. There was no significant difference in the feed efficiency of FWW and FWB treatments in the total growth period, compared with the CON treatment. Diets supplemented with $15 \%$ solid-state fermented feed had no difference in growth performance compared with pigs fed diets supplemented with antibiotics in growing-finishing figs (Hu et al., 2008). Missotten et al. (2010) reported that the feed efficiency was improved when growing-finishing pigs were fed fermented liquid diets. Liu et al. (2007) also showed that fermented soybean meal diets improved growth performance by $8.33 \%$ compared with non-fermented soybean meal diets. Rudbäck (2013) reported that acid (e.g. lactic acid, citric acid, and fumaric acid) metabolized through the citric acid cycle had a positive effect on the relatively high feed intake. However, in this study, the ADFI of FWW and FWB diets was significantly reduced. Canibe \& Jensen (2003) reported that growing pigs fed non-fermented liquid feed showed high feed intake compared with fermented liquid diets, which conforms with the findings of this study. Canibe et al. (2010) showed that feed intake decreased with increasing acetic acid concentration in feed.

The nutritional value of whole cereals was found to improve via ensiling. Fermented wheat and barley had a lower total NSP content than non-fermented cereals (Sholly et al., 2011), which could reduce the harmful effects on nutrient digestion (Marklinder \& Johansson, 1995). In a previous study, fibre diets supplemented with wheat bran could reduce total tract energy digestibility (Wilfart et al., 2007) and had a negative effect on carbohydrate digestibility (Le Gall et al., 2009). The DM and N digestibility was reduced when pigs were fed diets that included fibre (Noblet \& Perez, 1993). However, the digestibility of carbohydrate was increased when pigs were fed a fermented fibre diet, while total NSP was reduced (Jørgensen et al., 2010). In the current study, pigs that were fed $1.0 \%$ FWB showed reduced digestibility of DM, N, and GE, which may have had a negative impact on their growth. The digestibility of TDF, SDF, and IDF was significantly 
greater in pigs that were fed $0.5 \%$ or $1.0 \%$ FWW than in the CON group. Cho et al. (2013) showed that DM digestibility and $\mathrm{N}$ digestibility were improved when $50 \%$ of wheat in diets was replaced by fermented wheat. However, Zanfi \& Spanghero (2012) reported that the addition of whole ear maize silage in feeds had a negative effect on OM digestibility and NDF digestibility.

Microbes decompose polysaccharides into smaller polysaccharides or monosaccharides by fermentation in pigs' ceca and colons. These monosaccharides are then oxidized and turned into acetate, propionate, or butyrate. VFAs are efficiently absorbed in the large intestine and could work to facilitate the absorption of water and sodium (Yen, 2001). In the present study, the contents of acetic acid and butyric acid in faecal emissions were higher in pigs fed FWW and FWB diets than the CON diets. Pigs fed with high crude fibre levels could have increased VFA contents in ceca and colons (Giusi-Perier et al., 1989). Demecková et al. (2002) showed that feeding with fermented liquid feed increased acetic acid and propionic acid in sows. However, Cho et al. (2012) showed that fermented diets that were fed to pigs could reduce the concentration of acetic acid and propionic acid compared with non-fermented diets. Thus, the authors believe that the relationship between fermented feed and VFA concentration requires further investigation.

Rauw et al. (2007) reported a positive correlation between growth of pigs and HDL cholesterol, and a positive correlation between HDL cholesterol and triglyceride. In this study, the total cholesterol and triglyceride levels were lower than in pigs that were fed the CON diet. In previous studies, Loh et al. (2003) showed a decrease in plasma cholesterol levels in the fermented product group compared with the nonfermented product group in rats. Chu et al. (2011) reported that fermented diets could have an effect on reducing HDL and LDL cholesterol in fattening pigs. Blood cortisol levels were significantly decreased in the pigs that were fed FWW and FWB diets. The cortisol concentration was the lowest in the $1.0 \%$ FWW group. The cortisol concentration in the $0.5 \%$ FWW and 1.0\% FWB groups was lower than CON diets. Roh et al. (2015) showed that feeding pigs with diets containing $10 \%$ fermented soybean meal could reduce cortisol levels. Pigs fed $3.32 \%$ rye silage showed a positive effect on total cholesterol, triglyceride plasma, and cortisol level in blood (Cho et al., 2006). Han et al. (2001) reported that the growth hormone levels increased when the cortisol level was reduced. Thus, the authors hypothesized that the growth performance of the $1.0 \%$ FWW group was a numerically effective result owing to the low concentration of cortisol.

In the present study, faecal Lactobacillus and E. coli counts were not significantly different in treatments. The most well-studied external factor that influences the establishment of internal microbiota is diet (Demecková et al., 2002). In previous studies, supplement fermentation in diet affected the pathogenic bacteria in the intestine, such as E. coli, Salmonella spp. (Nout et al., 1989; Urlings et al., 1993; Jensen, 1998), and lactic acid. VFAs were able to reduce the numbers of Enterobacteriaceae (Prohaszka et al., 1990), which have beneficial effects on the intestinal health of pigs. Increased VFA could reduce the $\mathrm{pH}$ of the gastrointestinal tract. VFA in the gastrointestinal tract has a negative relation to the numbers of coliform bacteria in the faeces (Russell et al., 1996), and lowering the pH could improve the Lactobacillus count (Van Winsen et al., 2001).

\section{Conclusion}

This study was conducted to test the effects of feed supplementation with FWW and FWB. It was found that dietary inclusion of FWW and FWB had beneficial effects in lowering blood triglycerides and cortisol. Dietary inclusion of FWW had no negative effects on growth performance and could increase the digestibility of dietary fibre in growing pigs.

\section{Acknowledgements}

This study was carried out with the support of Cooperative Research Programme for Agricultural Science \& Technology Development (Project No. PJ011212), Rural Development Administration, Republic of Korea.

\section{Authors' Contributions}

J.H. CHO was in charge of project design. W. YUN and S.J. Park supervised the course of the study. J.H. Lee, W. G. Kwak and S.Y. Oh were in charge of sample collecting and participated in results and statistics. C.H. Lee wrote the manuscript and revised it.

\section{Conflict of Interest Declaration}

The authors declare that they have no conflict of interest.

\section{References}

AOAC, 2000. Official methods of analysis (17th ed.). Association of Official Analytical Chemists, Gaithersburg, MD, USA AOAC, 2006. Official methods of analysis (18th ed.). Association of Official Analytical Chemists, Arlington, Virginia, USA.

Brooks, P.H., 2008. Fermented liquid feed for pigs. CAB Reviews: Perspectives in Agriculture, Veterinary Science, Nutrition and Natural Resources 3, 18.

Canibe, N. \& Jensen, B.B., 2003. Fermented and non-fermented liquid feed to growing pigs: Effect on aspects of gastrointestinal ecology and growth performance. J. Anim. Sci. 81, 2019-2031. 
Canibe, N. \& Jensen, B.B., 2007. Fermented liquid feed and fermented grain to piglets-effect on gastrointestinal ecology and growth performance. Livest. Sci. 108, 198-201.

Canibe, N. \& Jensen, B.B., 2012. Fermented liquid feed - Microbial and nutritional aspects and impact on enteric diseases in pigs. Anim. Feed Sci. Technol. 173, 17-40.

Canibe, N., Pedersen, A.Ø. \& Jensen, B.B., 2010. Impact of acetic acid concentration of fermented liquid feed on growth performance of piglets. Livest. Sci. 133, 117-119.

Cho, J.H., Han, Y.K., Min, B.J., Kim, H.J., Yoo, J.S., Kim, J.W., Kim, I.H. \& Jin, Y.J., 2006. Effect of feeding rye silage and feed restriction on both growth and reproductive performances in replacing gilts. J. Anim. Sci. Tech.

Cho, J.H., Zhang, Z.F. \& Kim, I.H., 2013. Effects of fermented grains as raw cereal substitutes on growth performance, nutrient digestibility, blood profiles, and fecal noxious gas emission in growing pigs. Livest. Sci. 154, 131-136.

Cho, S.B., Cho, J.H., Hwang, O.H., Yang, S.H., Park, K.H., Choi, D.Y. \& Kim, I.H., 2012. Effects of fermented diets including grape and apple pomace on amino acid digestibility, nitrogen balance and volatile fatty acid (VFA) emission in finishing pigs. J. Anim. Vet. Adv. 11, 3444-3451.

Chu, G.M., Yang, B.S., Kim, H.Y., Kim, J.H., Ha, J.H., Kim, C.H., Lee, S.D. \& Song, Y.M., 2011. Effects of supplemental fermented agro by-products diet on the growth performances, blood characteristics and carcass traits in fattening pigs. Asian-Australas. J. Anim. Sci. 24, 1464-1472.

Demecková, V., Kelly, D., Coutts, A.G.P., Brooks, P.H. \& Campbell, A., 2002. The effect of fermented liquid feeding on the faecal microbiology and colostrum quality of farrowing sows. Int. J. Food Microbiol. 79, 85-97.

Den Besten, G., Van Eunen, K., Groen, A.K., Venema, K., Reijngoud, D.J. \& Bakker, B.M., 2013. The role of short-chain fatty acids in the interplay between diet, gut microbiota, and host energy metabolism. J. Lipid Res. 54, 2325-2340.

Giusi-Perier, A., Fiszlewicz, M. \& Rérat, A., 1989. Influence of diet composition in intestinal volatile fatty acid and nutrient absorption in unanesthetized pigs. J. Anim. Sci. 67, 386-402.

Givens, D.I., Humphries, D.J., Kliem, K.E., Kirton, P. \& Deaville, E.R., 2009. Whole crop cereals: 1. Effect of method of harvest and preservation on chemical composition, apparent digestibility and energy value. Anim. Feed Sci. Technol. 149, 102-113.

Han, Y.K., Kim, D.K. \& Lee, J.Y., 2001. Effects of Zizyphus Vulgaris supplementation on growth and blood cortisol and ßendorphin in weanling pigs. Kyunghee Med. 17, 183-186.

Hargreaves, A., Hill, J. \& Leaver, J.D., 2009. Effect of stage of growth on the chemical composition, nutritive value and ensilability of whole-crop barley. Anim. Feed Sci. Technol. 152, 50-61.

Hu, J., Lu, W., Wang, C., Zhu, R. \& Qiao, J., 2008. Characteristics of solid-state fermented feed and its effects on performance and nutrient digestibility in growing-finishing pigs. Asian-Aust. J. Anim. Sci. 21, 1635-1641.

Jensen, B.B., 1998. The impact of feed additives on the microbial ecology of the gut in young pigs. J. Anim. Feed Sci. 7 , $45-64$.

Jørgensen, H., Sholly, D., Pedersen, A.Ø., Canibe, N. \& Knudsen, K.E.B., 2010. Fermentation of cereals — Influence on digestibility of nutrients in growing pigs. Livest. Sci. 134, 56-58.

Knudsen, K.B. \& Hansen, I., 1991. Gastrointestinal implications in pigs of wheat and oat fractions. Br. J. Nutr. 65, 217232.

Le Gall, M., Serena, A., Jørgensen, H., Theil, P.K. \& Bach Knudsen, K.E., 2009. The role of whole-wheat grain and wheat and rye ingredients on the digestion and fermentation processes in the gut-a model experiment with pigs. Br. J. Nutr. 102, 1590.

Lei, Y. \& Kim, I.H., 2014. Effect of on performance, nutrient digestibility, blood characteristics, and meat quality in finishing pigs. J. Anim. Sci. 92, 171-176.

Lindberg, J.E., 2014. Fiber effects in nutrition and gut health in pigs. J. Anim. Sci. Biotechnol. 5, 1.

Liu, X., FENG, J., Xu, Z., Lu, Y. \& Liu, Y., 2007. The effects of fermented soybean meal on growth performance and immune characteristics in weaned piglets. Turk. J. Vet. Anim. Sci. 31, 341-345.

Loh, T.C., Foo, H.L., Tan, S.H., Goh, Y.M., Shukriyah, H.M. \& Kufli, C.N., 2003. Effects of fermented products on performance, faecal $\mathrm{pH}$, Enterobacteriaceae and lactic acid bacteria counts and interrelationships, and plasma cholesterol concentration in rats. J. Anim. Feed Sci. 12, 633-644.

Marklinder, I., Johansson, L., 1995. Sour dough fermentation of barley flours with varied content of mixed-linked $(1 \rightarrow 3)$, $(1 \rightarrow 4)$ B-d-glucans. Food Microbiol. 12, 363-371.

Meeske, R., 2005. Silage additives: Do they make a difference. S. Afr. J. Anim. Sci. 6, 49-55

Metzler, B.U. \& Mosenthin, R., 2008. A review of interactions between dietary fiber and the gastrointestinal microbiota and their consequences on intestinal phosphorus metabolism in growing pigs. Asian-Australas. J. Anim. Sci. 21, 603.

Metzler-Zebeli, B.U., 2007. Effects of fermentable carbohydrates and dietary P supply on bacterial $p$ incorporation, activity and composition in the gastrointestinal tract of pigs. Cuvillier Verlag, Göttingen.

Missotten, J.A., Michiels, J., Degroote, J. \& De Smet, S., 2015. Fermented liquid feed for pigs: an ancient technique for the future. J. Anim. Sci. Biotechnol. 6, 1.

Missotten, J.A., Michiels, J., Ovyn, A., De Smet, S. \& Dierick, N.A., 2010. Fermented liquid feed for pigs. Arch. Anim. Nutr. 64, 437-466.

Moran, C.A., Scholten, R.H., Tricarico, J.M., Brooks, P.H. \& Verstegen, M.W., 2006. Fermentation of wheat: Effects of 
backslopping different proportions of pre-fermented wheat on the microbial and chemical composition. Arch. Anim. Nutr. 60, 158-169.

Noblet, J. \& Perez, J. M., 1993. Prediction of digestibility of nutrients and energy values of pig diets from chemical analysis. J. Anim. Sci. 71, 3389-3398.

Nout, M.R., Rombouts, F.M. \& Havelaar, A., 1989. Effect of accelerated natural lactic fermentation of infant good ingredients on some pathogenic microorganisms. Int. J. Food Microbiol. 8, 351-361.

O'Connell, J.M., Sweeney, T., Callan, J.J. \& O'Doherty, J.V., 2005. The effect of cereal type and exogenous enzyme supplementation in pig diets on nutrient digestibility, intestinal microflora, volatile fatty acid concentration and manure ammonia emissions from finisher pigs. Anim. Sci. 81, 357-364.

Prohaszka, L., Jayarao, B.M., Fabian, A. \& Kovacs, S., 1990. The role of intestinal volatile fatty acids in the Salmonella shedding of pigs. Zoonoses. Public. Hlth. 37, 570-574.

Rauw, W.M., Portolés, O., Corella, D., Soler, J., Reixach, J., Tibau, J., Diaz, I. \& Gómez-Raya, L., 2007. Behaviour influences cholesterol plasma levels in a pig model. Animal 1, 865-871.

Roh, S.G., Carroll, J.A. \& Kim, S.W., 2015. Effects of fermented soybean meal on innate immunity-related gene expressions in nursery pigs acutely challenged with lipopolysaccharides. Anim. Sci. J. 86, 508-516.

Rudbäck, L., 2013. Organic acids in liquid feed for pigs - palatability and feed intake. Swedish University of Agricultural Sciences, Uppsala.

Russell, P.J., Geary, T.M., Brooks, P.H. \& Campbell, A., 1996. Performance, water use and effluent output of weaner pigs fed ad libitum with either dry pellets or liquid feed and the role of microbial activity in the liquid feed. J. Sci. Food. Agr. 72, 8-16.

Sholly, D.M., Jørgensen, H., Sutton, A.L. \& Richert, B.T., Bach Knudsen, K. E., 2011. Effect of fermentation of cereals on the degradation of polysaccharides and other macronutrients in the gastrointestinal tract of growing pigs. J. Anim. Sci. 89, 2096-2105.

Skrede, G., Sahlstrøm, S., Skrede, A., Holck, A. \& Slinde, E., 2001. Effect of lactic acid fermentation of wheat and barley whole meal flour on carbohydrate composition and digestibility in mink (Mustela vison). Anim. Feed Sci. Technol. 90, 199-212.

Urlings, H.A.P., Mug, A.J., van 't Klooster, A.T., Bijker, P.G.H., Van Logtestijn, J.G. \& Van Gils, L.G.M., 1993. Microbial and nutritional aspects of feeding fermented feed (poultry by-products) to pigs. Vet Q. 15, 146-151.

Van Winsen, R. L., Urlings, B.A., Lipman, L.J., Snijders, J.M., Keuzenkamp, D., Verheijden, J.H. \& van Knapen, F., 2001. Effect of fermented feed on the microbial population of the gastrointestinal tracts of pigs. Appl. Environ. Microbiol. 67, 3071-3076.

Wilfart, A., Montagne, L., Simmins, H., Noblet, J. \& Van Milgen, J., 2007. Digesta transit in different segments of the gastrointestinal tract of pigs as affected by insoluble fibre supplied by wheat bran. Br. J. Nutr. 98, 54-62.

Williams, C.H., David, D.J., \& lismaa, O., 1962. The determination of chromic oxide in faeces samples by atomic absorption spectrophotometry. J. Agric. Sci, 59, 381-385.

Yan, L., \& Kim, I.H., 2012. Effect of eugenol and cinnamaldehyde on the growth performance, nutrient digestibility, blood characteristics, fecal microbial shedding and fecal noxious gas content in growing pigs. Asian-Australas. J. Anim. Sci. 25, 1178.

Yen, J.T., 2001. Anatomy of the digestive system and nutritional physiology. In A. J. Lewis, \& L. Lee Southern (eds.), Swine nutrition, Second edition. CRC Press, Boca Raton, FL.

Zanfi, C. \& Spanghero, M., 2012. Digestibility of diets containing whole ear corn silage for heavy pigs. Livest. Sci. 145 , 287-291. 